\title{
A trafikpiac folytatódó átalakítása 2014 és 2017 között (Esettanulmány - kiterjesztett kutatás) LAKI MIHÁLY
}

A hazai piacon 2014 és 2017 között stabilizálódott a nemzeti dohányboltok száma. A trafikügyet kísérö közérdeklödés és izgatottság jelentösen csökkent. A piac ilyen állapotában az állam radikálisan átalakitotta a hazai dohánytermék-nagykereskedelmet. A ,hivatalos” indok a nagykereskedők eröfölénye volt, ám ez nem magyarázta, hogy miért hozták létre ezen a piacon a magyar gazdaságban egyedülálló, a kis-és a nagykereskedök/termelök közé ékelt Országos Dohányboltellátó Kft.-t. Cikkünkben bemutatjuk egyik tulajdonosának kivételezett helyzetét, ám a dohánytermékpiac szabályozásának ismétlődö kudarcai is hozzájárultak a vállalat megalapitásához, a termékpálya-szabályozás radikális átalakitásához.

Journal of Economic Literature (JEL) kód: D43, D52, H13

A dohánytermékpiacról folytatott kutatásunk eredményeit bemutató korábbi cikkben és mühelytanulmányban a 2014-es országos választások utánig, az új kormány megalakulásáig követhettük nyomon az eseményeket (Laki, 2014, Laki, 2015a, Laki, 2015b). Az utóbbi három évben újságolvasóként, internetfogyasztóként továbbra is dokumentáltam, nyomon követtem a trafikpiac eseményeit. Most másodlagos források feldolgozásával és az érintett vállalatok és intézmények illetékeseivel folytatott konzultációk alapján a kutatás kiterjesztésére vállalkozom. Azt próbálom kideríteni, hogy a 2012-2014-es szabályozásmódosítás sorozata után hogyan változott a dohánytermékek hazai piaca. ${ }^{1}$

https://doi.org/10.47630/KULG.2017.61.7-8.46

Laki Mihály, az MTA KRTK Közgazdaság-tudományi Intézetének tudományos tanácsadója. E-mail: laki.mihaly@krtk.mta.hu

${ }^{1}$ Cikkünk az OTKA által támogatott A piacszabályozás nem várt következményei és hatásai címủ kutatási projekt visszatérő - kibővítő kutatásának eredményeit tartalmazza. Köszönöm Bisztray Márta, Karsai Gábor, Madarász Aladár, Major Iván, Piroska Dóra, Réti Pál, Szalai Júlia, Vince Péter, 


\section{Elmélet és módszer - rövid áttekintés}

A kiterjesztés és visszatérés során a korábbi kutatás elméleti megfontolásait és módszertanát alkalmaztuk. ${ }^{2}$ A kapitalista gazdaságokban a piaci tranzakciók mellett alkuhelyzetekre bukkanhatunk a társadalom hétköznapi életében éppúgy, mint a pártpolitika világában, vagy a hatalmi ágak vagy a kormányzás intézményei közötti kapcsolatokban. (Johansen, 1981, 103. o.)

A szocialista országokban az alku jellemzően az állami tulajdonban levő vállalatok és a tervezési központ között, illetve vállalati hierarchia szintjei között zajlott. ${ }^{3}$ A tervezési hierarchia alsóbb szintjein levők a tervfeladatok csökkentésében, lazításában, a felettesek a feszítésben voltak érdekeltek. Nem hagyhatjuk figyelmen kívül azonban, hogy a terv- és a szabályozóalkuk a szocialista rendszer hatalmas államiszövetkezeti szektorán belül zajlottak. ${ }^{4}$ A mi történeteinkben azonban az állam olyan piac újraelosztására, újraállamosítására vállalkozik, ahol a magánvállalkozók, vállalkozások a piacra lépés jogát bérlik az államtól, miközben a vállalkozás müködtetéséhez szükséges ingatlan és berendezések magántulajdonban vannak és maradnak.

Tárgyunk szempontjából fontos a szabályalkotó állam befolyásolása, a lobbizás is, amely „a kapcsolatok kiépítését és fenntartását, negatív intézkedések hatásának kivédését, előnyök szerzését stb. szolgálja, szigorúan a törvényes keretek adta lehetőségek között". ${ }^{5}$ A hazai lobbiszabályozás és a hatásai számos ponton eltérnek az amerikaitól ${ }^{6}$ és a nyugat-európaitól. A legnagyobb különbség - jórészt emiatt helyezték hatályon kívül az első magyar lobbitörvényt 2010-ben -, hogy Magyarországon „minimális volt a regisztrált lobbisták száma”, „hogy a láthatatlan vagy informális lobbizás dominált a gyakorlatban”, továbbá ,a szankcionálás sem müködött”. (Dr. Alexa-Dr. Burai-Dr. Inzelt, 2012, 14-15. o.) A magyar esetek kutatásában ezért csak körültekintően, fenntartással hasznosíthatjuk a lobbizás gazdaságtanának újabb eredményeit (Igan-Mishra-Tressel, 2009, Kaiser, 2009).

\footnotetext{
Voszka Éva segító, bíráló megjegyzéseit. Köszönöm Czeglédi Zoltánnak (KRTK Adatbank) a gondos adatgyüjtést és feldolgozást. Névtelenséget ígértem a szakmai interjúk, konzultációs beszélgetések résztvevőinek. Köszönöm, hogy bővítették ismereteimet, értelmezték a piacszabályozási folyamatokat.

${ }^{2}$ Korábbi tanulmányaink olvasói nyugodtan átugorhatják ezt a fejezetet.

3 A kérdés hatalmas irodalmából lásd: Kornai [1957], Kornai-Lipták [1965], Gács-Lackó [1974], Antal [1985].

${ }^{4}$ A szocializmus tulajdonviszonyairól folyó vita ismertetésétől megkíméljük az olvasót.

${ }^{5}$ Lásd: http://hu.wikipedia.org/wiki/Lobbiz\%C3\%A1s

${ }^{6}$ Az egyesült államokbeli lobbizás kutatásának friss eredményeiről lásd: Vidal-Draca-FonsRosen [2011].

7 2006. évi XLIX. törvény.
} 
Az Albert O. Hirschman [1995] által bevezetett, a tömegesen elöforduló, jellegzetes cselekvéseket leíró fogalmak (kivonulás, tiltakozás, hüség) is segítették a radikális szabályozóváltozások hatásainak leírását és értelmezését. A kivonulást azonban nem önkéntesen, hanem az új szabályokat alkalmazó hatóságok kényszerének engedve hajtják végre a magyar vállalatok vagy a háztartások az általunk vizsgált termék- és szolgáltatáspiacokon. A kényszerített és az önkéntes kivonulás helyett a gazdaság szereplői több esetben a tiltakozást választják: „A vállalat fogyasztói, illetve a szervezet tagjai közvetlenül is kifejezhetik elégedetlenségüket: vagy a vállalat, illetve a szervezet vezetőségének, vagy a fölöttes hatóságnak, vagy pedig - általános tiltakozás révén - bárkinek, aki hajlandó meghallgatni őket. Ezt a lehetőséget tiltakozási opciónak nevezzük. A folyamat eredményeképpen a vállalat vagy a szervezet vezetőségének ismét kísérletet kell tennie arra, hogy föltárja az elégedetlenség okait s orvosolja az érintettek panaszait." (Hirschman, 1995, 12. o.)

A Neil Fligstein [2001] nyomán kidolgozott tagolást, szakaszolást is eredménynyel használtuk a rendszerváltás utáni piacfejlődés leírására, elemzésére. A leírt és elemzett termék- és szolgáltatáspiacokon jellemzően egymást követte ,az új szereplők tömeges beáramlása, az ezt gyakran követő piaci zavar, a piac tisztulása, a zavarok elhárítása”. (Laki, 2011, 32. o.) A rendszerváltás utáni piacfejlődés elemzése, a robusztus változások leírása során azonban kevés figyelmet fordítottunk a vertikális piaci tranzakciókra, a piacszintek gyakran eltérő állapotára, müködésére.

Így jártunk el a dohánytermékpiac rendszerváltás utáni fejleményeit bemutató korábbi tanulmányunkban is (Laki, 2015a). A piacszabályozás változtatásainak kezdeményezői között találtuk a termelő- és a nagykereskedő vállalatok tulajdonosait, de a radikális szerkezeti változások a kiskereskedelemben zajlottak. A figyelmünk ezért elsősorban a dohánytermék-kiskereskedelem szabályozásának változásaira, a módosítások következményeire irányult.

A továbbiakban kiterjesztjük az elemzést: a 2014 utáni időszakban ismét bemutatjuk a dohánytermék-kiskereskedelmi piac elhúzódó és továbbra sem sikeres konszolidálódását, ám - új elemként - áttekintjük a nagykereskedelem piaci zavaroktól is kisért radikális átalakulását, átalakitását is. 


\section{Ahol abbahagytuk}

Korábbi kutatásunkban egy szabályozási kudarcot dokumentáltunk: a 2012-es „eredeti” szabályozást, ${ }^{8}$ az úgynevezett trafiktörvényt másfél év alatt hétszer módosították a nem várt és a negatív következményei ${ }^{9}$ miatt. Kiderült, hogy „A pártfogolt nagyvállalatok és főként a piac új, kijelölt szereplői (a koncessziót elnyertek vagy a másodlagos piacon koncessziót vásárlók, szerzők) is hozzájárultak a szabályozási kudarchoz. Nem elhanyagolható részük megalapozatlan, túlzottan optimista üzleti tervekkel lépett a piacra. Rendre nem számoltak a piac zsugorodásával, és föként a feketepiaci forgalom gyors bővülésével. Nem mérték fel kellő gondossággal a boltjaik térbeli elhelyezkedésének a forgalomra gyakorolt hatását. Az elégedetlen, csalódott új szereplők, a koncesszióért pályázók, a pályázatot fontolgatók ezért tiltakozással és kivonulással és tárgyalásos alkuk során üzentek a piacot szabályozó, a koncessziószerzés feltételeit megszabó államnak." (Laki, 2015a, 49. o)

A zavarok fö forrása, hogy a rejtett politikai céljait követö állam átrendezte, újraszervezte a piacot. A szabályozás kudarcai: a dohányárusítási pontok nélkül maradt másfélezer település, a piacra lépésre vállalkozók vártnál kisebb, a veszteséges új vállalkozások vártnál nagyobb száma gyors visszacsatolásra, folyamatos korrekcióra késztette a szabályozó államot és képviselöjét, az állami társaságot. Ezért bővítette az állam a nemzeti dohányboltokban árusítható termékek és szolgáltatások körét, enyhítette a dohánytermék-forgalmazás elkülönítésének szabályait, ezért jogosította fel a kisebb települések polgármestereit a dohánytermék-forgalmazók kijelölésére. Innen ered a szabályozás hatásait, a piaci szereplők alkalmazkodását türelemmel kivárni nem képes állami magatartás. „A korrekciók azonban újabb szabályozási zavarokat, feszültségeket okoztak és újabb szabályozómódosításokhoz vezettek." (Laki, 2014, 50. o.)

${ }^{8}$ 2012. évi CXXXIV. törvény a fiatalkorúak dohányzásának visszaszorításáról és a dohánytermékek kiskereskedelméröl.

${ }^{9}$ „A gazdaságpolitika és szabályozás e sikermutatói azonban nem mérik a magyar többségi tulajdonban levő, a dohányforgalom megszünése miatt megszűnt dohányboltokat, meggyengült kisboltokat, vendéglőket és a dohányáruk feketekereskedelmének növekedése miatti jövedelem kiesésének az új nemzeti dohányboltok és a költségvetés bevételeire gyakorolt negatív hatását. Ezek a nem tervezett negatív hatásai (veszteségei) a trafiktörvénynek.” (Laki, 2015a, 48. o.). 


\section{Piaci folyamatok a 2014-es választások után}

A piac konszolidálódásának jele, hogy a sajtó érdeklődése az elmúlt három évben csökkent, nagyságrenddel kevesebb tudósítás, riport jelent meg a trafikügyekröl, dohánytermék-fogyasztástól, mint korábban. A feszült, időnként hisztérikus légkör enyhülését jelzi, hogy a visszaélések feltárására, dokumentálására létrehozott internetes felületeken 2014 után már nem találtunk friss kommentárokat. ${ }^{10}$

A növekvő nyugalmat jelzi az is, hogy a nemzeti dohányboltok száma nem változott jelentősen, de valamelyest csökkent az elmúlt három évben. A trafikok felszámolása és a koncessziók sajátos elosztása miatt indított jogi eljárások (perek, beadványok) is véget értek 2015-ben. (Lásd az 1. táblázatot.) ${ }^{11}$

1. táblázat

\section{A nemzeti dohányboltok száma}

\begin{tabular}{cccc}
\hline Év & $\begin{array}{c}\text { Koncessziós szerződéssel ren- } \\
\text { delkező dohánybolt }\end{array}$ & Kijelölt dohánybolt & Összesen \\
\hline 2014 & 5890 & 466 & 6356 \\
2015 & 5628 & 494 & 6122 \\
2016 & 5512 & 566 & 6078 \\
\hline
\end{tabular}

Forrás: ND Nonprofit Zrt. közlése.

Mindez - mint hamarosan bemutatjuk - nem jelent változatlanságot. Számos új elöírás, szabály módosította 2014 második felétől 2017 tavaszáig a dohány-kiskereskedők költségeit és hasznait, a vállalkozásuk müködési feltételeit. A legfontosabb szerkezeti és szabályozási változások azonban a dohányáru-nagykereskedelemben zajlottak le.

A választások előtt, 2014 elején, érzékelve az új dohányboltok közötti jelentős és növekvő forgalom- és profitkülönbségeket, a kormány újból átrendezte a piacot. „Május 30-tól nem müködhet trafik benzinkúton és 2500 négyzetméternél nagyobb

${ }^{10}$ Lásd: http://trafikmutyi.cafeblog.hu/

${ }^{11}$ A magyar bíróságok és az Alkotmánybíróság rendre a régi trafikosok ellen ítélkeztek, az európai bíróságok pedig a magyar államot marasztalták el. Az AB azzal érvelt, hogy nem sérült a korábbi trafikosok tulajdonhoz való joga. Csak azért, mert évekig árusítottak dohányt hatósági engedéllyel, a gazdasági tevékenységük még nem vált tulajdonná, tehát az engedély elvonása nem számít kisajátításnak. Lásd: http://index.hu/gazdasag/2014/07/08/ab_nem_jogos_az_extrafikosok_panasza/ 
alapterületủ üzlethelyiségben, ilyenek például a plázák és a hipermarketek, és fontos szabály, hogy ezek parkolójában sem, tehát még a plázától leválasztva sem.”12

Ez a szabálymódosítás csak részben váltotta be a hozzá füzött reményeket. A hazai dohánytermékpiacon, 2014 első negyedévében ugyanis visszaesett a legális forgalom. 2013 negyedik negyedévében még 123477 millió forint volt a dohányáruforgalom, 2014 első negyedében pedig 118922 millió. „Normális piaci körülmények között ritkán fordul elő, hogy májusban kevesebb cigaretta fogy, mint áprilisban, de most ez is megtörtént. Májusban (2014 májusában - L. M.) mindössze 660 millió szál cigaretta fogyott Magyarországon, míg áprilisban 690 millió szál.”"13 „Tavaly májushoz képest ez közel 200 millió szál visszaesést jelent, de 2012 májusában például 1,1 milliárd szál szerepelt az adóhatóság statisztikáiban. Idén májusig pedig összesen 2,9 milliárd szál fogyott, ez több mint egymilliárd szállal kevesebb, mint 2013 azonos időszakában."'14

Föként a feketekereskedelem növekedése okozhatta a dohányboltok forgalmának több hónapos visszaesését: „A GfK Hungária... felmérése ${ }^{15}$ a feketepiac drasztikus megerősödését mutatta. A forgalomnak a múlt nyáron (2013 nyarán - L. M.) még nyolc százalékát tette ki a zugáru, ez a téli hónapokra 12 százalékra nőtt. Iparági becslések szerint azonban ez is meghaladott állapot, a feketepiac már ennél is nagyobb lehet.” (Batka, 2014a) „A feketepiac megerősödéséhez egy újabb adat. - Hetvenegymillió szál lefoglalt cigaretta. Ez a mennyiség ugyanannyi, mint amennyit 2013-ban egész évben lefoglaltak a kollégáink - számszerűsít... a Nemzeti Adó- és Vámhivatal vám- és jövedéki szóvivője, és hozzáteszi: nőtt a csempészési kedv, amit a pénzügyőrök rendre »elrontanak«."16

A kedvezőtlen piaci folyamat néhány hónap után véget ért, a dohányáru-forgalom 2014 második felében gyors növekedésbe fordult. Az éves forgalom 28,9 százalékkal haladta meg az elöző évit (lásd a 2. táblázatot). Ez is hozzájárult, hogy a dohányboltok átlagos nyeresége jelentősen nőtt: „2013-ban egy fél év is elég volt ahhoz, hogy 50 százalékos mutatót hozzanak össze a trafikok. Hogy mekkora szó ez, jól mutatja, hogy a 2013 közepi trafikújraosztásig 10-20 százalék között - tehát vol-

12 Lásd: http://inforadio.hu/belfold/2014/05/23/juniustol_nem_lehet_trafik_a_benzinkutakon_ es_a_plazakban-639245

${ }^{13}$ Lásd: http://inforadio.hu/belfold/2014/05/23/juniustol_nem_lehet_trafik_a_benzinkutakon_ es_a_plazakban-639245

${ }_{14}$ Lásd: http://index.hu/gazdasag/2014/07/21/meg_soha_nem_fogyott_ilyen_keves_cigaretta_magyarorszagon/

152014 nyarán készült a felmérés.

${ }^{16}$ Lásd: http://www.szon.hu/erosodik-a-feketekereskedelem/2624241 
taképpen ott, ahol más szektorokban, a nemzetgazdasági átlag közelében - mozgott a csak cigarettát, dohányárut árusító cégek sajáttőke-arányos nyeresége."17

2. táblázat

\section{A dohányáru-kiskereskedelem forgalma}

\begin{tabular}{ccc}
\hline Év & A dohányáru-kiskereskedelem forgalma (Millió Ft) & Előző év $=100 \%$ \\
\hline 2012 & 328148 & 118,8 \\
2013 & 414305 & 126,2 \\
2014 & 534924 & 128,9 \\
2015 & 560829 & 104,9 \\
2016 & 586432 & 104,6 \\
\hline
\end{tabular}

Forrás: https://www.ksh.hu/docs/hun/xstadat/xstadat_eves/i_okfb002.html

A növekvö haszon azonban szélsöségesen oszlott meg a dohányboltok között: „A nagyjából hatezer trafikból csak hozzávetőleg kétezer képes nyereséget vagy nullaszaldós forgalmat produkálni." ${ }^{18}$ Nagy területi különbségek jöttek létre: „Az, hogy csak minden tizenkettedik, vagy jó esetben minden hatodik trafikosnak megy jól, főként az elhelyezkedéssel magyarázható... Budapesten, vidéki nagyvárosokban, a nyugati határszélen sok kuncsaftjuk van a dohányboltosoknak, máshol azonban pangás van - és ebbe belejátszik az is, hogy az illegális piac egyre nagyobb szeletet hasít ki." ${ }^{19}$

\section{A nyolcadik szabálymódosítás}

2014 novemberében a kormány benyújtotta újabb elöterjesztését, amelynek címe „A fiatalkorúak dohányzásának visszaszoritásáról és a dohánytermékek kiskereskedelméröl szóló 2012. évi CXXXIV. törvény módositásáról." ${ }^{20}$ A módosítás részletes indoklásában Hegmanné Nemes Sára államtitkár a boltokban értékesithetö termékek körének újabb bövitését szorgalmazta: „A javaslat célja a dohányboltban forgalmazható termékkör észszerü, minimális bővítése olyan termékekkel, amelyek a trafi-

${ }^{17}$ Lásd: http://hvg.hu/gazdasag/20150619_Taroltak_az_osztrak_hatarnal_a_trafikok

${ }^{18}$ Lásd: http://index.hu/gazdasag/2014/05/14/a_trafikok_fele_vergodik/

${ }^{19}$ Lásd: http://hvg.hu/gazdasag/20150619_Taroltak_az_osztrak_hatarnal_a_trafikok

${ }^{20}$ Lásd: http://www.parlament.hu/irom40/02080/02080.pdf 
kok árukínálatához szervesen kapcsolódnak. A javaslat lehetővé teszi elsősorban a rágógumi és mentolos termékek (cukorkák, lapocskák), továbbá tömegközlekedési jegyek árusítását, valamint a mobiltelefon egyenlegének feltöltését." ${ }^{\text {21 }}$ A kínálat bővítése jelentős, de kevesebb volt a vártnál: ,a trafiklobbi nem volt egészen sikeres, információink szerint arra hajtottak, hogy az energiaitalokat és a tömény szeszeket is kizárólag a trafikokban lehessen kapni."22

A dohánybolt-alapításhoz elöírt minimális lakosságszám emelése nehezítette az újak, a később érkezők piacra lépését, javította a koncesszióval rendelkezők versenyhelyzetét. A törvényt előterjesztő államtitkár asszony szerint: „A forgalmi adatok alapján az szürhető le, hogy a dohányboltok törvény által lehetővé tett száma meghaladja a piaci igényeket jelenleg. A jövőben ennek fokozatos csökkentése indokolhatóvá és indokolttá válik.” ${ }^{23}$ Ezért: „A javaslat - a jövőre nézve - megemeli azt a küszöböt, amelyet követően újabb dohánytermék-kiskereskedelmi jogosultság kiírását a törvény kötelezővé teszi. A korábban 2000 fő után kiírt egy jogosultságot a javaslat a felével megemeli; a hatályba lépést követően úgy kell a pályázatokat kiírni, hogy a küszöb 3000 fö legyen. Ezen túlmenően, ha ezt a forgalmi adatok (várhatóan) indokolják, de legalább két jogosultságot az adott településen gyakorolnak, a kiíró dönthet úgy is, hogy nem az összes - a törvény által elöírt számú - jogosultságot engedi át, csak ennél kevesebbet. Ezzel biztosítani lehet azt, hogy olyan településeken, ahol - bár a lakosságszám ezt lehetővé tenné, de - a fogyasztók száma ezt nem indokolja, a maximálisnál kevesebb számú dohánybolt működjön.” ${ }^{24}$ A törvénymódosítás, miközben javítja a nemzeti dohányboltosok piaci helyzetét, „növeli függésüket az államtól: a kormány megszüntethet trafikokat ott, ahol feleslegesnek érzi, és erről saját maga dönthet, nincs odaírva, mi alapján, teljes egészében diszkrecionális jogkörben, önkényesen dönthet így a miniszter. A javaslat megteremti annak lehetőségét, kifejezetten felhatalmazva a koncessziós szerződés megkötésére jogosult minisztert, illetve a nevében eljáró személyt arra, hogy azokon a területeken, ahol a dohányboltok számának csökkentése indokolt lehet, a jogosulttal a koncessziós szerződés megszüntetésére megállapodás születhessen.”25

${ }^{21}$ Lásd: http://www.parlament.hu/irom40/02080/02080.pdf

${ }^{22}$ Lásd: http://nol.hu/gazdasag/kormanyzati-lelegeztetogepre-kerulnek-a-trafikok-1499195

${ }^{23}$ Lásd: http://orszaggyules.hu.sayit.parldata.eu/orsz\%C3\%A1ggy\%C5\%B11\%C3\%A9s2014-/33-\%C3\%BCl\%C3\%A9snap-20141126-felsz\%C3\%B31al\%C3\%A1sai/\%C3\%A1ltal\%C3\%A1n os-vita-lefolytat $\% \mathrm{C} 3 \% \mathrm{~A} 1$ sa-t 2080 -a-fiatalkor $\% \mathrm{C} 3 \%$ BAak-d H

${ }^{24}$ Lásd: http://www.parlament.hu/irom40/02080/02080.pdf

${ }_{25}$ Schiffer András hozzászólása. Lásd: http://orszaggyules.hu.sayit.parldata.eu/orsz\%C3\%A1ggy\%C5\%B11\%C3\%A9s-2014-/33-\%C3\%BCl\%C3\%A9snap-20141126-felsz\%C3\%B31al\%C3\%A1sai/ \%C3\%A1ltal\%C3\%A1nos-vita-lefolytat\%C3\%A1sa-t2080-a-fiatalkor\%C3\%BAak-d 


\section{További szabályozásváltozások}

Hamarosan újabbak követték a nyolcadik szabálymódosítást. „A nemzeti trafikokat megsegítendő, a dohány árrését tízről 13 százalékra pumpálják fel 2014 végén." (Batka, 2014b)

A nemzeti dohányboltban árusitható termékek körének egy újabb bövitése is kedvezően érinthette a bolthálózatot. 2015 decemberében a parlament az egészségügyről hozott törvény keretében újraszabályozta az elektronikus cigaretta forgalmazásának feltételeit. Az Emberi Erőforrások Minisztériuma által benyújtott törvényjavaslat az Európai Unió jogharmonizációs irányelveire hivatkozva „egységesítette” az elektronikus és a hagyományos cigarettára vonatkozó szabályozást. ${ }^{26}$ Így „....az elektronikus cigarettákat is csak a trafikokban lehetne megvásárolni. Használni pedig csak a kijelölt helyeken, vagyis nagyjából a hagyományos cigarettára vonatkozó szabályok lesznek érvényesek az e-cigire is .... A nyugati határszélen a föként osztrák vevőket kiszolgáló, nyereséges és tőkeerős boltok, bolthálózatok éppúgy kizárólagos joggal árusíthatják az e-cigarettát, mint a fennmaradásukért küzdő kisvárosi dohányboltok." ${ }^{27}$

Hamarosan kiderült azonban, hogy a nagyobb árrés és a kibővített kínálat sem tette vonzóvá a dohányboltnyitást, fơként a kis falvakban. Ezért újabb pályázatot írtak ki 2015 első hónapjaiban. ${ }^{28}$ Ezeken a kisebb településeken lehetett koncessziót szerezni. Ekkor sem történt lényeges változás. Mindössze 66 nyertest hirdettek ki, közülük hússzal nem is sikerült szerződést kötni a megadott határidőn belül. ${ }^{29} 464$ helyen nem volt jelentkező. ${ }^{30} \mathrm{Az}$ ilyen falvakban ,az eddigi boltosok nagy részének megengedték, hogy »kijelölés« alapján tovább árulhassák a cigarettát, amíg valaki nem jelentkezik a koncesszióért”. (Batka, 2015a) Jellemzően a településen müködő hagyományos vegyesboltban forgalmazzák a kijelölt boltosok a dohányárut. 2014ben 466, 2016-ban már 566 kijelölt dohánybolt működött az országban. (Lásd az 1. táblázatot.)

26 2016. évi CLXXII. törvény Az egyes egészségügyi és egészségbiztosítási tárgyú törvények módosításáról Lásd: https://net.jogtar.hu/jr/gen/hjegy_doc.cgi?docid=A1600172.TV\&timeshift=fffffff $4 \&$ txtreferer $=00000001 . T X T$

${ }^{27}$ Lásd: http://hvg.hu/gazdasag/20150619_Taroltak_az_osztrak_hatarnal_a_trafikok

${ }^{28}$ Lásd: http://nemzetidohany.hu/palyazatok-2/2015-04-02-an-kiirt-palyazat/

${ }^{29}$ Lásd: http://nemzetidohany.hu/wp-content/uploads/Eredményhirdetés-weboldalra_2015.06.02..pdf

${ }^{30}$ Lásd: http://nemzetidohany.hu/wp-content/uploads/Eredménytelenségi_hirdetmény0615_2. pdf 
Az eddigiek alapján állíthatjuk, hogy a dohány-kiskereskedelem szabályozásának újabb módosításai sem oldották meg a 2012-es törvény által átalakított piaci környezet folyamatos feszültségeit (a jelentős feketekereskedelmet, a dohányboltok többségének gyenge profitabilitása, a dohányboltot eltartani nem bíró falvak százait).

\section{A nagykereskedelem átalakítása}

Már néhány hónappal a 2012-es törvény elfogadása után, 2013 nyarán több hírt olvashattunk arról, hogy a kormány a dohány-nagykereskedelmi piac átalakításától is az említett gondok és feszültségek enyhítését várja. ${ }^{31} \mathrm{Az}$ ötlet majdnem egy évig „pihent”, majd a fejlesztési miniszter 2014. november 17-én az őszi jogalkotási programban nem szereplő újabb törvénymódosítást terjesztett a parlament elé (Tamás, 2014, 15. o.). ${ }^{32}$ Az előkészítő Nonprofit Zrt. és az elöterjesztő miniszter, noha nem konzultált a dohányipar illetékeseivel, ${ }^{33}$ a dohány-nagykereskedők piaci eröfölényével indokolta a módosítást.

Az olvasó addig ismeretlen fogalmakkal ismerkedhetett meg a három törvényt is módosító ${ }^{34}$ 2014. évi XCV. törvény ${ }^{35}$ „A megbízható dohánykereskedővel a dohánykiskereskedelem-ellátási tevékenység elvégzése céljából megköthető koncessziós szerződésre irányadó különös szabályok” című fejezetében.

Az olvasója megtudja, mi a dohánykereskedelem-ellátás, hogy néz ki egy dohány-kiskereskedelmi ellátó. A későbbi fejlemények megértéséhez különösen fontos a megbízható kereskedő definíciójának a törvényben szokatlanul ritka részletessége:

„Megbízható dohánykereskedő: az a személy, amely a nemzeti vagyonról szóló 2011. évi CXCVI. törvény 3. § (1) bekezdés 1 . pontja szerinti átlátható szervezet és

a) 2005. január 1. óta valamennyi, az állami adóhatóság által nyilvántartott, 500000 Ft-ot meghaladó közteherre vonatkozó bevallási és fizetési kötelezettsé-

${ }^{31}$ Lásd: http://nol.hu/gazdasag/kozpontositjak_a_dohanytrafikok_ellatasat_is__-1386631

32 Lásd: http://www.parlament.hu/irom40/02080/02080.pdf

33 „A Dohányipari Befektetők Magyarországi Szövetségének (DBMSZ) elnöke, Dezső Lóránt sokkal észszerűbbnek tartotta volna, ha a kormányzat a törvény benyújtása előtt konzultált volna a dohányiparral.” Lásd: http://www.origo.hu/gazdasag/20141118-megszivja-a-trafik2-t-a-dohanyipar.html

${ }_{34}$ Ekkor módosították A fiatalkorúak dohányzásának visszaszorításáról és a dohánytermékek kiskereskedelméről szóló 2012. évi CXXXIV. törvényt, A koncesszióról szóló 1991. évi XVI. törvényt és A jövedéki adóról és a jövedéki termékek forgalmazásának különös szabályairól szóló 2003. évi CXXVII. törvényt.

35 2014. évi XCV. törvény a dohánytermék-kiskereskedelem integrált ellátásához szükséges egyes törvények módosításáról. 
gének eleget tett, és ilyen kötelezettsége teljesítésével egyszer sem esett 90 napot meghaladó késedelembe,

b) 2005. január 1. óta egyik bankszámláján sem volt 500000 Ft-ot meghaladó azonnali beszedési megbízás az adóhatóság részéről, illetve müködése során nem indult ellene 500000 Ft-ot meghaladó érték tekintetében végrehajtási eljárás,

c) müködése során, azzal összefüggésben, nem történt olyan jogsértés, amely miatt esetenként húszmillió forint összeget meghaladó bírsággal sújtották volna,

d) legalább 15 éven keresztül folytatott olyan, a dohánytermékek nagykereskedelmi értékesítésére irányuló tevékenységet, amelyhez engedéllyel rendelkezett és amely engedély alapján a Jöt.-ben meghatározott alábbi személyek valamelyikének minősült dohánytermék vonatkozásában:

da) adóraktár engedélyese (gyártó),

db) importáló,

dc) bejegyzett kereskedő,

dd) jövedéki engedélyes kereskedő." ${ }^{36}$

További fontos fejlemény, hogy A nemzeti vagyonról szóló 2011. évi CXCVI. törvényt is módosították a dohányellátás új rendszere miatt: az állam kizárólagos gazdasági tevékenységei közé került a dohány-kiskereskedelem ellátási tevékenység. ${ }^{37}$

Az érdekvédelmi szervezetek különbözőképpen értékelték az új szabályozást. „A Magyar Dohány Kiskereskedők Egyesülete (MDKE) kedvező fordulatként értékeli, hogy a dohánykereskedelmet szabályozó törvény tervezett módosítása optimalizálja a müködési feltételeket, egyúttal fellép egyes piaci szereplök tisztességtelen üzleti gyakorlata ellen - mondta Adorjánné Pordán Éva, az MDKE titkára az egyesület sajtótájékoztatóján. Kiemelte, a piac müködőképességének fenntartásához megoldásra váró kérdések között szerepelt a szállítók és kiskereskedők szerződéses kapcsolata, amely az utóbbi időben olyan mértékben egyoldalúvá vált a szállítók javára, hogy az már-már veszélyeztette a trafikosok megélhetését, a dohányboltjaik működését. Elmondta: a mostani körülmények között a szállítási szerződések megkötéséhez és az áruszolgáltatáshoz a dohánytermék-nagykereskedők elvárják, hogy az egyoldalúan összeállított szerződést változatlan formában írják alá a kiskereske-

${ }^{36}$ Lásd: https://mkogy.jogtar.hu/?page=show\&docid=a1400095.TV

37 „A nemzeti vagyonról szóló 2011. évi CXCVI. törvény 12. § (1) bekezdés 1) pontja helyébe a következő rendelkezés lép: (Az állam kizárólagos gazdasági tevékenységei a következök:)

„1) dohánytermékek kiskereskedelme, illetve a dohánykiskereskedelem-ellátási tevékenység” Lásd: http://www.kozlonyok.hu/nkonline/MKPDF/hiteles/MK14183.pdf 
dők, másrészt olyan kapcsolódó elvárásokhoz kötik a dohányáruk szállítását, mint a "polckép « fenntartása." ${ }^{38}$

Ezzel szemben „A Dohányipari Befektetők Magyarországi Szövetségének tagjai elfogadhatatlannak tartják a kormányzat legújabb törvényjavaslatát, mely előzetes szakmai konzultáció nélkül államosítaná a dohánytermékek nagykereskedelmét. A dohányipari vállalatok álláspontja szerint az intézkedés felesleges, költséges, bonyolulttá teszi a kiskereskedelmi ellátást, valamint sérti a szabad verseny és a vállalkozás szabadságának Alaptörvénybe foglalt jogát, az EU Alapjogi Chartát, emellett az uniós és hazai versenyszabályokat is. ... A dohányipari szereplök értetlenül állnak a törvényjavaslat indokolásának »egyes nemkívánatos piaci jelenségekkel« és »káros nagykereskedôi magatartásokkal« kapcsolatos állításai előtt, mert nem érzékeltek olyan horderejü problémákat a piacon, amelyek az átmeneti időszak átlagos nehézségeit meghaladnák, és amelyek a piaci folyamatokba történő ilyen drasztikus beavatkozást indokolnák. Nem helytálló az az állítás sem, hogy a gyártók nagykereskedelmi tevékenységüket változatlanul folytathatják. A dohány-kiskereskedelmi ellátó klasszikus nagykereskedelmi tevékenységet végez, még ha a törvény ki is veszi a nagykereskedelmi definíció hatálya alól.’’39

A tiltakozásnak nem volt foganatja. Rövid parlamenti vita után, 2014. december 24-én kihirdették a törvényt. Azt, hogy egyes érdekeltek számára milyen fontos lehetett az ügy, a sok törvénymódosítás mellett az is jelzi, hogy „A Ház a változtatással egyben a kétharmados többséget igénylö sarkalatos törvények közé is emelte a jogszabályt". ${ }^{40}$

Nem tudtuk kideríteni, hogy mi történt a törvény kihirdetése utáni első hónapokban. Egy 2015. május 7-i sajtóhírből azonban már arról értesülhettünk, hogy „A dohányiparban egy másik nagyhatású lépés sem kizárt. Lázár elmondta, hogy a fejlesztési minisztérium dolga előkészíteni egy javaslatot a központi dohányelosztóról. Ennek a létrehozását akkor támogatja a kormány, ha a kiskereskedőket megvédi a nagy multiktól, jelezte a miniszter. Ha így lesz, a dohánytermékek beszerzését központosíthatják." ${ }^{\prime 1}$

A kizárólagos állami tevékenységnek nyilvánított dohány-kiskereskedelem ellátását állami vállalat alapításával, vagy egy már müködő állami vállalat tevékenységi körének kibővítésével is megszervezhették volna az illetékesek. Ám a koncesszió-

${ }^{38}$ Lásd: http://hvg.hu/kkv/20141119_Ragot_is_a_nemzeti_dohanyboltbol_a_trafik

${ }^{39}$ Lásd: http://www.dbmsz.hu/read.php?aid=121

${ }^{40}$ Lásd: http://www.napi.hu/magyar_gazdasag/megszavaztak_az_allami_trafikellatot_leepites_ es_adoemeles_jon.591000.htm

${ }^{41}$ Lásd: http://hvg.hu/kkv/20150507_A_kormany_atverte_a_dohanycegeket 
ba adás mellett döntöttek. A 2014. évi XCV. törvény szerint „A dohánykiskereskedelem-ellátási feladatokra vonatkozó koncessziós szerzödést nyilvános pályázat eredményeként, vagy a Ktv. 10/D. §-a alapján kell megkötni úgy, hogy a dohánykiskereskedelem-ellátás az egész ország területén biztosított legyen. Koncessziós szerződés a nyilvános pályázat nyertesével vagy olyan személlyel köthető, amelyik megbízható dohánykereskedőnek, illetve e személy legalább többségi tulajdonában álló gazdasági társaságnak minősül, és amelyik ... meghatározott jövedéki engedélylyel rendelkezik." ${ }^{42}$

A koncessziós ajánlat

A későbbi fejleményeket jelentősen befolyásolta az ugyancsak a 2014. évi XCV. törvényben elfogadott szabályozás, hogy „Az ágazati miniszter mellőzheti a nyilvános koncessziós pályázat kiírását, ha a koncessziós szerződés megkötésére megbízható dohánykereskedővel, vagy e személy legalább többségi tulajdonában álló gazdasági társasággal is sor kerülhet" ${ }^{43}$

Ezt a jogi lehetőséget használta ki a piac egyik jelentős szereplője, a Continental Dohányipari Csoporthoz tartozó Tabán Trafik Zrt. A Continental csoport 2015. június 1-jén ajánlatot tett a magyar állam nevében eljáró Nemzeti Fejlesztési Minisztériumnak dohánykiskereskedelem-ellátási tevékenység végzésére. A „Tevékenységet az Ajánlattevő tulajdonában levő társaság útján vállalja végezni, mely a Koncessziós Törvény szerződő fele lenne az ajánlat kedvező elbírálása esetén. Ajánlattevő vállalja, hogy a társaságot a pécsi BAT Pécsi Dohánygyár Kft.-vel közösen korlátolt felelösségű társaság formában alapítja meg és müködteti. Ajánlattevő vállalja, hogy a létrehozandó kft.-ben többségi részesedéssel rendelkezik és a többségi üzletrészét a koncessziós szerződés hatálya alatt mindvégig fenntartja." ${ }^{4}$

\section{A koncessziós szerződés}

A két vállalat 2015. június 1-jén tett koncessziós ajánlatát június 19-én fogadta el a kormány. Az érdekeltek - a minisztérium, a BAT Pécsi Dohánygyár Kft. (ki-

${ }^{42}$ Lásd: http://www.parlament.hu/irom40/02081/02081-0007.pdf

${ }^{43}$ Lásd: http://www.parlament.hu/irom40/02081/02081-0007.pdf

${ }^{44}$ Lásd: http://www.kormany.hu/download/c/e9/60000/Koncesszios_szerzodes_2015junius. pdf\#!DocumentBrowse 
sebbségi tulajdonos), a Tabán Trafik Zrt. (mint Megbízható Kereskedő), valamint a Koncessziós Társaság - képviselői egy hónappal később, 2015. július 19-én aláírták a koncessziós szerződést.

Az időközben megalapított Országos Dohánybolt Ellátó Kft. (a továbbiakban: ODBE) volt a szerződést aláíró koncessziós társaság. „A dohánykiskereskedelmiellátási tevékenység folytatása céljából kötött koncessziós szerződés szerint a dohány-kiskereskedelmi ellátási feladatokat az Országos Dohánybolt Ellátó Kft. ... látja el állami felügyelet mellett. A jogszabályi elöírások értelmében az ODBE 2015. november 1. napjától köteles a dohánytermékeket - a dohánytermék-kiskereskedők folyamatos igénye, megrendelései, illetve az ellátás biztonsága megszervezésének szempontjaira figyelemmel - a dohánytermék-nagykereskedőktől megvásárolni (beszerezni), készleten tartani és raktározni, a dohánytermék-kiskereskedőknek értékesíteni és részükre kiszállítani, valamint a jogszabályban meghatározott feladatokat ellátni." ${ }^{\text {45 }}$

\section{A dohány-nagykereskedelmi piac radikális átalakulása}

A koncessziós szerződés gyorsan és radikálisan átalakította a piaci tranzakciók szerkezetét és irányát: „2015. november 1. napjától központi dohányellátó hivatott a jövőben a dohánytermék-kiskereskedők dohánytermékkel történő ellátását biztosítani. A jogszabályi előírás alapján a központi dohányellátó valamennyi hazai dohánytermék-nagykereskedővel köteles szerződést kötni, így a dohánytermék-kiskereskedők megkülönböztetés és versenyhátrány nélkül szerezhetik be árukészletüket. A szakszerủ elosztórendszernek köszönhetően a dohánytermék-kiskereskedők kizárólag olyan fajtájú és mennyiségű dohányterméket rendelhetnek meg, amelyet ténylegesen értékesíteni tudnak, beszerzéseikről tehát saját üzleti megfontolásaik, valamint forgalmi igényeik függvényében dönthetnek, ezáltal üzemeltetési költségeik is mérséklödhetnek." ${ }^{46}$

„Lázár János tájékoztatása szerint a nagykereskedelmi tevékenységre 2014. december 24. óta a két cég tett közös ajánlatot. Orbán Viktor miniszterelnök felhatalmazta a nemzeti fejlesztési minisztert, hogy a szerződést, 600 millió forint konceszsziós díj fejében kösse meg”47 - szólt a 2015. júniusi hír.

${ }^{45}$ Lásd: http://nemzetidohany.hu/informaciok/orszagos-dohanyboltellato/

${ }^{46}$ Lásd: http://nemzetidohany.hu/informaciok/orszagos-dohanyboltellato/

${ }^{47}$ Lásd: http://hvg.hu/kkv/20150617_Kifakadtak_a_gyartok_a_kozponti_dohanyell\# 
A dohány-nagykereskedők és a termelők nem olvasták volna a vonatkozó törvényszövegeket kellő alapossággal? Nem vették észre a törvénymódosítást, amely jórészt a Continental cégcsoport fontos jellemzőit tette a szerződéskötés feltételévé?

Ha észrevették, nyugtathatták magukat azzal, hogy más vállalatok is megfelelnek a feltételeknek. „A megadott paraméterek alapján a cégtárban keresve csupán néhány cég jön szóba. A feltételek tökéletesen illenek a kormányközelinek tudott Continental Dohányipari Zrt. disztribúciós cégére, a Tabán Trafik Kft.-re. ... Elvileg befutó lehet még a Vimpex is, amely szintén régi szereplő a piacon, és a befolyásosnak tartott cég körül is több tucat trafikból álló hálózat alakult ki. Szóba jöhet még két dohány-nagykereskedő cég, mindkettő a Csetényi Csaba - Krskó Tibor páros érdekeltsége. Két kakukktojásra is leltünk: a Róna Dohányfeldolgozó Kft., amelyhez semmilyen trafikmutyival kapcsolatos hír nem kötődött - az általunk megkérdezett piaci szereplők pontosan ezért nem is tippeltek az országszerte amúgy kiterjedt hálózattal rendelkező Rónára. Végül az egyik multi, a JTI cége is több mint 15 éve van a piacon és nem tudni rájuk kirótt, komoly büntetésröl sem.” (Botka, 2014a, 6. o.)

A külföldi tulajdonban levö nagyobb dohánykereskedö és termelövállalatok negatív várakozásait erősíthette, hogy a kormány további ügyekben is a kisebb vállalatoknak, köztük a Continental cégcsoportnak kedvező szabályozást vezetett be ezekben a hónapokban, például az ekkor kivetett egyszeri egészségügyi hozzájárulásnál. Az indoklás szerint „A törvényjavaslat sávosan határozza meg a fizetendő hozzájárulás mértékét - szintén az igazságosabb közteherviselés jegyében. A hozzájárulás mértéke az adóalap 30 milliárd forintot meg nem haladó része után $0,2 \%$, de legalább harmincmillió forint, az adóalap 30 milliárd forintot meghaladó, de 60 milliárd forintot meg nem haladó része után 2,5\%, az adóalap 60 milliárd forintot meghaladó része után 4,5\%. A sávos fizetési kötelezettség a piacon arányaiban nagyobb részesedéssel bíró dohányipari vállalkozásokat arányosan nagyobb teherrel sújtja, de a kisebb vállalkozások is kénytelenek mindenképpen kivenni részüket az egészségügyi kiadások finanszírozásából." ${ }^{48}$

A baljós jelek ellenére a piac szereplői kivártak, nem tettek ajánlatot. „Arra számítottunk, hogy kiírják a koncessziós pályázatot. Ehhez igazítottuk a terveinket"\$4_ mondta egyik beszélgetőpartnerünk.

${ }^{48}$ Lásd: http://www.parlament.hu/irom40/02027/02027.pdf

${ }^{49}$ Interjúrészlet. 
Az ellenajánlat

A Continental-BAT tulajdonában álló Országos Dohánybolt Ellátó Kft. számára igen kedvezö volt, hogy „a koncessziós díjat a »tevékenység ellátásával kapcsolatos jelentős beruházási kötelezettségeket figyelembe véve« fokozatosan vezetik be. Így a koncessziós díj idén (2015-ben - L. M.) kerek tízmillió forint lesz. 2016-ban százmillió forint, majd ezt követően évente százmillió forinttal emelkedik. A koncesszió jogosultja 2021-től minden évben hatszázmillió forintot köteles koncessziós dijként fizetni. Az üzemeltetési költségeket is figyelembe véve iparági becsléseink 5-10 milliárd közé tették a trafikellátó hasznát. Különösen, hogy míg a trafikok két héten belül kell, hogy fizessenek, addig a trafikellátó két hónap után kell csak, hogy kiegyenlítse a számlát." ${ }^{50}$

Ezek után Magyarországon korábban nem tapasztalt esemény tanúi lehettünk. A hoppon maradt cégek (Imperial Tobacco Magyarország Kft., a JTI Hungary Zrt. és a Philip Morris Magyarország Kft.) összefogtak, és bejelentették, hogy ajánlatot tesznek a koncesszióért. Jelentősen emelték is a tétet: „a három vállalat az ajánlatában évente lépcsőzetesen növekvő, 6 milliárd forintig terjedő koncessziós díjat vállal, tekintettel arra, hogy egyrészt a kijelölt ellátó - a jogszabályban meghatározott feltételek alapján - várhatóan nagyon magas nyereséget érhet el, mely ezen vállalatok becslései szerint akár az évi 16 milliárd forintot is elérheti. Másrészt a kormány a koncessziót 20 évre adja meg, és ezzel hosszú távú kiszámíthatóságot helyez kilátásba." ${ }^{51}$

„Továbbá: egy jogállamban elfogadhatatlannak tartjuk, hogy az állam zárt eljárásban, nem transzparens szempontrendszer alapján válasszon ki egy olyan konceszsziós jogosultat, amely évente jelentős extraprofitot érhet el minimális üzleti kockázattal, melyet a dohányipari vállalkozások és a fogyasztók finanszíroznak." ${ }^{52}$

„A három cég szerint az államnak nyílt pályázatot kellett volna kiírnia. Szerintük a kiválasztás folyamata átláthatatlan volt, aminek a végén a kormány az egyéb cégektől kapott ajánlat hiányára hivatkozva hirdette ki a BAT Pécsi Dohánygyárat és a Tabán Trafikot. Szerintük, ha nyílt eljárás lett volna, akkor nemzetközi tapasztalatok alapján az általuk most ígért sokmilliárdos koncessziós díjat tudta volna beszed-

${ }^{50}$ Lásd: http://nol.hu/gazdasag/az-allam-bago-penzert-dobta-oda-a-milliardos-dohanyuzletet-1540809

${ }^{51}$ Lásd: http://www.tmkronika.hu/hirek/santa-torveny-es-a-dohany-nagykereskedelem-mintallatorvosi-lo

${ }^{52}$ Lásd: uo. 
ni az állam, nem 10 vagy százmilliót. Ezért azt kérik, hogy a kormány gondolja újra a koncesszió odaítélésének a folyamatát." ${ }^{53}$

A kormány azonban nem gondolta újra a koncesszió odaitélésének folyamatát. A Nemzeti Fejlesztési Minisztérium 2015. június 25-én közreadott állásfoglalása szerint: „Az NFM kénytelen az Ajánlattevő Magyarország Kft. ajánlatát - mint érvénytelent és értelmezhetetlent - az Ajánlattevőnek elfogadás nélkül visszaküldeni. A tárca hangsúlyozza: bár a koncessziós szerződést a szolgáltatásra - az egész ország területére vonatkozóan - már megkötötte ugyan, és ezért eleve kénytelen lenne az Ajánlattevő ajánlatát visszautasítani, az ajánlat elfogadásra e körülménytől teljesen függetlenül is alkalmatlan." 54

Az indoklás szerint, ,az Ajánlattevő ajánlata maga zárta ki azt, hogy az ajánlata valóban - a törvény értelmében - elfogadható ajánlatnak minősüljön. Az Ajánlattevő jogilag nem kötelezö erejü, legfeljebb tárgyalási alapnak szánt, s nem a miniszter által elfogadható ajánlatnak nyilvánitotta a saját Ajánlatát, amelytöl ö maga bármikor, jogi kötelezettségvállalás nélkül visszavonulhat.” Továbbá ,,a koncessziós szerződés aláírásától kezdődő 5. évtől a központi költségvetésröl szóló törvény határozza meg azt, hogy mekkora legyen a koncessziós dij mértéke: ugyanakkor az Ajánlattevö ezt csak akkor tartaná magára nézve kötelezönek, ha ez az összeg nem nagyobb, mint a nettó nyereségének 45 százaléka. Ilyen, a törvény konkrét rendelkezésével ellentétes vállalást az NFM nem is hagyhat jóvá."

Ugyancsak itt olvashatjuk, hogy ,nincs benne semmilyen számítás vagy minimális üzleti terv sem. Ebből következően a miniszter felelősséggel nem is tudja megítélni, hogy van-e bármilyen reális alapja annak, hogy a vállalt koncessziós díjat - amely egyébként a csökkenő piac mellett soha nem érné el a sajtóban megjelent ajánlati összeget - az Ajánlattevő egyáltalán teljesíteni tudja-e.”

„Kérdéses - és az ajánlatból egyáltalán nem kideríthető - az, hogy az Ajánlattevő és annak tulajdonosa valóban átlátható szervezetnek minősül-e;” valamint ,az ajánlat egyértelműen arról rendelkezik, hogy a tevékenységet nem a törvény által elöírt koncessziós társaság látná el, hanem azt kiszerveznék egy külföldi tulajdonú cégnek, a spanyol Logista elnevezésü társaságnak. A tevékenység teljes kiszervezésére azonban a törvény nem ad lehetöséget." "55

${ }^{53}$ Lásd: https://444.hu/2015/06/24/elkepeszto-ajanlattal-igertek-ra-a-konkurensek-az-allam-altal-kivalaszott-dohany-nagykereskedokre

${ }^{54}$ Lásd: http://www.kormany.hu/hu/nemzeti-fejlesztesi-miniszterium/vagyonpolitikaert-felelosallamtitkarsag/hirek/allasfoglalas-az-imperial-tobacco-magyarorszag-kft-ajanlataval-kapcsolatban

${ }^{55}$ Lásd: http://www.kormany.hu/hu/nemzeti-fejlesztesi-miniszterium/vagyonpolitikaert-felelosallamtitkarsag/hirek/allasfoglalas-az-imperial-tobacco-magyarorszag-kft-ajanlataval-kapcsolatban 
Az elutasitással szinte egy időben egy újabb kormányrendelet is életbe lépett, „, amely a közérdekre hivatkozva nemzetstratégiai jelentöségünek minősítette a BAT Pécsi Dohánygyár és a Tabán Trafik összefonódását." ${ }^{56}$ A munkahelyteremtéssel és az ellátás biztonságával indokolt nemzetstratégiai jelentőségüvé minősítés miatt így azután a Gazdasági Versenyhivatal nem vizsgálhatja az Országos Dohánybolt Ellátó Kft. piaci részesedését, „pedig szakértők szerint egy ilyen mamutcég aligha állná ki versenytörvénynek a monopóliumok létrejöttét korlátozó paragrafusainak a próbáját". ${ }^{57}$

\section{Ellenállás - behódolás}

Az ellenajánlat elutasítása után az érintett vállalatok többsége elfogadta a kormány feltételeit, a megadott feltételek szerint szerződött az Országos Dohánybolt Ellátó Kft.-vel (ODBE) az új rendszer szerinti szállításra. „Az ODBE Kft. tájékoztatása szerint az Alföld Tabak Kft.-vel, a BAT Pécsi Dohánygyár Kft.-vel, a Continental Dohányipari Zrt.-vel, a Danczek Dohányipari Kft.-vel, a Tabán Trafik Zrt.-vel és a TTI Hungary Kft.-vel kötöttek szerződést." ${ }^{58}$ Néhány vállalat azonban - kedvező brüsszeli bírósági döntésre várva - halasztotta a szerződést: „Sajnos egyes gyártók és importörök - habár erre minden lehetőségük adott volt az elmúlt hetekben, vélelmezhetően összehangolt magatartásukkal nem csatlakoztak ehhez... Bíznak abban, hogy szem előtt tartva a kiskereskedők ellátásának biztonságát, a törvényben meghatározott átmeneti időszakban ezek a gyártók és importőrök is csatlakozni fognak a rendszerhez." ${ }^{59}$

Nyomásgyakorlásuk legfontosabb eszköze a várható választék- és áruhiány volt: „A trafikosok egyelöre a piaci kínálat töredékéből tudnak csak válogatni, mivel a hazai dohánypiac nagyobb részét lefedő multinacionális cégek, a Philip Morris, a Japan Tobacco és az Imperial továbbra sem írta alá az együttműködési szerződést az ODBE-vel. A trafikok november közepéig még eldönthetik, hogy a trafikhoz kiszállító gyártóktól, vagy az ODBE időközben megnyitott raktáraiból vásárolnak, igaz, utóbbi helyeken csak a British American Tobacco (BAT), a Continental Zrt., valamint néhány kisebb hazai gyártó termékei közül választhatnak. November 17-től

${ }^{56}$ Lásd: http://nepszava.hu/cikk/1061216-monopolium-lett-a-dohanykereskedelem

${ }^{57}$ Lásd: http://nepszava.hu/cikk/1061216-monopolium-lett-a-dohanykereskedelem

${ }^{58}$ Lásd: http://www.origo.hu/itthon/20151028-hat-ceggel-kotott-szerzodest-az-orszagosdohanyboltellato.html

${ }^{59}$ Lásd: http://www.origo.hu/itthon/20151028-hat-ceggel-kotott-szerzodest-az-orszagosdohanyboltellato.html 
azonban már kizárólag az OBDE-n keresztül juthatnak dohányáruhoz. Ha a nagyok addig nem szerződnek le a nagykereskedőcéggel, úgy elvileg nem árusíthatnak Magyarországon, ez pedig komoly áruhiánnyal fenyeget." ${ }^{90}$

\section{Hogyan épül fel és múködik az ODBE?}

A 2015. november 17-es határidő után az addig vonakodó cégek is betagozódtak a rendszerbe. Innentől termékeiket az ODBE közvetítésével szállították a dohánykiskereskedőknek.

Az ODBE országos vállalat. Részvényeinek 51 százaléka a Continentál csoport tulajdonában van, a BAT a kisebbségi tulajdonos, 49 százalékos részesedéssel. A két tulajdonos egy-egy igazgatót delegál, akik egyenlő döntési jogokkal és kompetenciával irányítják a vállalatot. A vállalat felügyeleti szerve a ND Nemzeti Dohánykereskedelmi Nonprofit Zrt. ${ }^{61}$

A vállalat kilenc nagykereskedelmi raktárból álló országos hálózatának a logisztikai központját a vecsési depóban állították fel. ${ }^{62}$ A nagykereskedők, a termelők az ODBE logisztikai programjait követve, bizományosi szerződéseiknek megfelelően ezekbe a raktárakba szállítják dohánytermékeiket. A kiskereskedők elektronikus vagy személyes rendelései alapján összeállított „csomagjait” a vállalat gépjármüvei innen szállítják a dohányboltokba, illetve a dohánytermékek árusítására kijelölt vegyesboltokba. Az ODBE minden megbízást köteles teljesíteni: „szerződéses kötelezettséggel rendelkezik a gyártók és nagykereskedők irányába, versenysemleges müködése során az egyes gyártók és nagykereskedők között megkülönböztetést nem tehet, a kiskereskedők rendelését nem befolyásolhatja". ${ }^{3}$

${ }^{60}$ Lásd: http://www.origo.hu/gazdasag/20141118-megszivja-a-trafik2-t-a-dohanyipar.html

${ }^{61}$ „Az ND Nonprofit Zrt. feladatkörét az Fdvtv. 4. § (2) bekezdése határozza meg, melynek c) pontja jelöli meg a dohány-kiskereskedelmi ellátóval megkötött Koncessziós Szerződésekben foglaltak betartásának ellenőrzését. Ezen ellenőrzési feladatkört a megkötött koncessziós szerződés 6 . pontja is megerősíti azáltal, hogy a Magyar Állam, illetőleg a képviseletében eljáró Miniszter a Koncessziós Szerződés aláírását megelőzően meghatalmazta az ND Nonprofit Zrt.-t a Koncessziós Szerződés alapján Koncesszióba adót megillető jogok gyakorlásában és kötelezettségek teljesítésében való közremüködéssel, különös tekintettel a Koncessziós Szerződés rendelkezéseinek Koncessziós Társaság általi betartásának ellenőrzésével."

ND-ÁLT/589-6/2017 - Tájékoztatás kutatással kapcsolatos megkeresés témában

62 Lásd: http://www.vecseshirek.hu/2015/12/10/vecsesen-mukodik-az-orszagos-dohanyboltellato-logisztikai-kozpontja/

63 Lásd: http://www.bat.hu/group/sites/BAT_ABLKYM.nsf/vwPagesWebLive/DOABLMAW 
Mikor sikeres az ODBE? Milyen mutatók alapján értékelik a menedzsment teljesítményét?

1. A vállalatnak legalább annyi nyereséget kell termelnie, hogy az évről évre 100 millió forinttal növekvő koncessziós díjat befizesse a költségvetésnek. Különösen a 2021 utáni időszak évi 600 millió forintnyi koncesszió díjának „kitermelése” kíván majd jelentős erőfeszítéseket (lásd a 3. táblázatot).

2. „A Felek megállapodnak, és Koncessziós Társaság - ajánlatában foglaltak szerint - kötelezettséget vállal arra, hogy a jelen Koncessziós Szerződésben számára engedett jogosultság gyakorlásával összefüggésben legalább 400 főt (átlagos éves statisztikai létszám) foglalkoztat a tevékenységnek a teljes Területi Egységen való megkezdését követő 3, azaz három éven keresztül.” ${ }^{94}$

\section{A koncessziós szerződésben előírt koncessziós díj}

\begin{tabular}{lll}
\hline Időszak & $\begin{array}{c}\text { Koncessziós díj/naptári év/teljes területi egység, azaz } \\
\text { a } 19 \text { megye és Budapest teljes közigazgatási területe }\end{array}$ & Fizetési határidő \\
\hline 2015 & $10000000 \mathrm{Ft}$ & 2015. október 31. \\
2016 & $100000000 \mathrm{Ft}$ & 2016. január 31. \\
2017 & $200000000 \mathrm{Ft}$ & 2017. január 31. \\
2018 & $300000000 \mathrm{Ft}$ & 2018. január 31. \\
2019 & $400000000 \mathrm{Ft}$ & 2019. január 31. \\
2020 & $500000000 \mathrm{Ft}$ & 2020. január 31. \\
$2021-2033$ & $600000000 \mathrm{Ft}$ & Minden naptári év január 31. \\
2034 & $500000000 \mathrm{Ft}$ & 2034. január 31. \\
\hline
\end{tabular}

Forrás: http://www.kormany.hu/download/c/e9/60000/Koncesszios_szerzodes_2015junius. pdf\#!DocumentBrowse

3. A koncessziós szerződés kötelezi az ODBE-t, hogy gondoskodjon az ellátás biztonságáról: „A Koncessziós Társaság... 2015. november 2. napján a Területi Egység teljes közigazgatási területén, azaz valamennyi megyében és Budapesten megkezdi a tevékenység végzését, és azt a Koncessziós Szerződés hatálya alatt fo-

${ }^{64}$ Lásd: http://www.kormany.hu/download/c/e9/60000/Koncesszios_szerzodes_2015junius. pdf\#!DocumentBrowse 
lyamatosan végzi akként, hogy az ellátás a tevékenység megkezdésétől a teljes Területi Egységen teljes körben biztosított legyen." ${ }^{65}$

A szabályozáselemzést nehezíti, hogy a magyar jog és szabályozás nem ismeri az ellátási biztonság vagy felelösség általánosan érvényes meghatározását. Ismerünk parciális meghatározásokat, ${ }^{66}$ ám esetünkben a törvényhozó nem határozta meg, mit ért az ellátás biztonságán. Nem rendelkezik arról, hogy kinek az ellátását kell biztosítani, és az sem derül ki a szövegekből, hogy mikor biztonságos az ellátás.

Az egyik lehetséges értelmezés, hogy az ellátás akkor biztonságos, ha a dohányboltok rendszeresen és időben hozzájutnak a megrendelt dohánytermékekhez. A másik - és ez emlékeztet a szocializmus gumifogalmára, az ellátási felelősségre ${ }^{67}$ -, hogy a vállalatnak biztosítania kell a szállításaival lefedett terület (értsd az egész ország) dohánycikkellátását, és ehhez a nemzeti dohányboltok és a kijelölt boltok tartós és zökkenömentes müködését.

Az első értelmezésnek ad teret a szerződés 8. pontja. „Koncessziós Társaság vállalja, hogy ... a Területi Egységen saját költségén a jogszabályok szerinti valamennyi, a Fdvtv. szerinti dohánykereskedelem-ellátót terhelő feladatot elvégzi, ennek keretében a dohánytermékeket - a kiskereskedők folyamatos igénye, megrendelései, illetve az ellátás biztonsága megszervezésének szempontjaira figyelemmel a dohánytermék-nagykereskedőktől megvásárolja (beszerzi), készleten tartja és raktározza, a kiskereskedőknek értékesíti és kiszállítja, valamint egyéb, jogszabályban meghatározott feladatokat lát el." 68

A második értelmezés mellett szól, hogy „A hatályos törvény a trafikos teljes értékesítésével fordítottan határozza meg az alkalmazható árrést: ez a cigaretta esetében 10 és 11,5 százalék között, az egyéb dohánytermékek esetében 10 és 13 százalék között lehet, azaz minél nagyobb egy trafik forgalma, annál kisebb árrésre

${ }^{65}$ Lásd: http://www.kormany.hu/download/c/e9/60000/Koncesszios_szerzodes_2015junius. pdf\#!DocumentBrowse

${ }^{66}$ A 2011. évi CCIX. törvény a viziközmü-szolgáltatásról például így fogalmaz: „Az ellátási felelősség elve: e törvényben meghatározottak szerint az állam vagy a települési önkormányzat (a továbbiakban együtt: ellátásért felelős) kötelessége és joga gondoskodni a közmüves ivóvízellátással és a közmüves szennyvízelvezetéssel és -tisztítással kapcsolatos víziközmü-szolgáltatási feladatok elvégzéséröl. Lásd: https://net.jogtar.hu/jr/gen/hjegy_doc.cgi?docid=a1100209.tv

${ }^{67}$ „Az ellátás fogalma lényegéből következően nem egzakt, hiszen annak eldöntése, hogy az adott körülmények között mely szükségletek fontosak, és azok milyen színvonalú kielégítése indokolt, nagyon sok szubjektív elemet tartalmaz. Még inkább így van ez az ellátási felelősséggel, hiszen ebben az esetben nemcsak az ellátás színvonalának minősítése szubjektív, de a felelősség megítélése is ..." (Karsai, 1988, 64-65. o.)

${ }^{68}$ Lásd: http://www.kormany.hu/download/c/e9/60000/Koncesszios_szerzodes_2015junius. pdf\#!DocumentBrowse 
jogosult. Vagyis a kisebb forgalmú trafikokat kompenzálja a szabályozás. A módosítás azonban nem az eladott termék mennyiségéhez kötné az árrést, hanem ahhoz, hogy a vállalkozás mennyit vásárolt a trafikellátótól." (Batka, 2015a) Azaz az ODBE, felhasználva az árréskülönbségeket támogathatja a kedvezötlen piaci körülmények között tevékenykedö kisebb dohánytermék-kiskereskedöket. A jövedelem átcsoportosítása javítja a dohányboltok, a trafikhálózat fennmaradásának, stabilitásának - és ezzel a biztonságos ellátásnak - az esélyeit. Mindez nem feltétlenül növeli, inkább csökkenti a vállalat profitját. „Az ellátási felelősség lényegéből következően ellátást kér számon, s ennek során lényegében figyelmen kívül hagyja ennek ráfordításoldalát, gazdaságosságát.” (Karsai, 1988, 64-65. o.)

\section{A termelők és a nagykereskedők az új piaci szerkezetben}

A sikertelen ellenajánlat után a piac összes szereplője alkalmazkodott az új szabályozáshoz és beszállítói szerződést kötött az ODBE-val. Az új szabályozás nem lehetetleníti el, de erősen szükíti tevékenységi körüket: „A nagykereskedők az új szabályozást követően is tovább végezhetik a disztribúción kívüli nagykereskedelmi tevékenységüket, mint például az árubeszerzés, termékválaszték-menedzsment, az ODBE mint viszonteladó részére történő értékesítés." ${ }^{99}$ Ilyen feltételek mellett néhányan eléggé borúlátóan ítélték meg a növekedési vagy akár fennmaradási esélyeiket az új szabályozási-piaci szerkezetben. „Ha lesz trafik2, vagyis az állam által kijelölt dohány-kiskereskedelmi ellátó létrejön, akkor a cégemnek »game over« - mondta a föleg dohánytermékek importjával és nagykereskedelmével foglalkozó Pannon Tabacco ügyvezető igazgatója az Origónak. A vízipipadohányt és szivarokat is forgalmazó cég nyeresége tavaly 70 millió forint volt. A Pannon Tabaccónak 77 alkalmazottja van, és mindannyian utcára kerülhetnek, ha államosítják a dohánynagykereskedelmet." 70

„A budaörsi székhelyű Rónatabak Dohányforgalmazó Kft. tavaly 124 millió forint nyereséget könyvelt el. Apáti Béla, a cég ügyvezető igazgatója az Origónak azt mondta, ha elfogadják a hétfön benyújtott törvényjavaslatot, az súlyosan érintené a cégét. Jelenleg 130-an dolgoznak nála, egyelöre nem mert becslésekbe bocsátkozni, hogy hány ember állása kerülhet veszélybe. Apáti Béla szerint a trafik2 miatt

${ }^{69}$ Lásd: http://www.bat.hu/group/sites/BAT_ABLKYM.nsf/vwPagesWebLive/DOABLMAW

${ }^{70}$ Lásd: http://www.origo.hu/gazdasag/20141118-megszivja-a-trafik2-t-a-dohanyipar.html 
újra kellene terveznie a vállalkozásait."71 A vállalat kereskedelmi partnereihez írt levelének alábbi részlete jól mutatja az alkalmazkodás jellegzetes módszereit: „A Rónatabak Kft. 2015. november 17. után is rendszeresen látogatni fogja az összes Nemzeti Dohányboltot! 2015. november 17-től a Rónatabak Kft. tevékenységét az alábbi formában folytatja:

- Továbbra is tölünk szerezhetik be azokat a cigarettahüvelyeket (Club, Primus, Energy) és dohányzási kiegészítőket (Smoking és Energy cigarettapapírok, Primus töltő, Firelight öngyújtók stb.), amit eddig is forgalmaztunk.

- Szállítani fogunk a Nemzeti Dohányboltban értékesíthető egyéb termékeket is: többek között kávé, energiaital, szeszesital is elérhető lesz a rendszerünkben.

Képviselőink és értékesítőink a dohánytermékek megrendelésével és kihelyezésével kapcsolatos tanácsadással fogják segíteni az önök munkáját."72

Ma még nem tudjuk, hogy az ,indirekt marketing" "73 és a választékbővítés ilyen és hasonló módszerei elegendőek lesznek-e a túléléshez ennél a vállalatnál. Két év eseményei nemcsak ennél a vállalatnál, de általában sem elegendőek a piaci fejlemények, túlélési esélyek értékeléséhez. Három - 2014-es forgalmuk és az alkalmazott létszám alapján kisebb-közepes méretű - dohány-nagykereskedelmi vállalat ${ }^{74} 2016$ ra befejezte (vagy szünetelteti) működését. Nem tudjuk, hogy korábbi gyengébb teljesítményük, vagy az új piacszabályozás miatt jutottak-e erre az elhatározásra.

2014 és 2016 között jelentősen változott a talpon maradt vállalatok - éves forgalom és átlagos létszám alapján mért - teljesítménye. A változások egyértelmü nyertesei az Országos Dohánybolt Ellátó tulajdonosai: a BAT növelte, a Continental lényegében stabilizálta forgalmát és alkalmazottainak létszámát, miközben a kizárólag az ODBE közvetítésével kereskedőknél a forgalom és a létszám - néhány kisebb vállalat kivételével - jelentősen visszaesett (lásd a 4. és 5. táblázatot).

${ }^{71}$ Lásd: http://www.origo.hu/gazdasag/20141118-megszivja-a-trafik2-t-a-dohanyipar.html

${ }^{72}$ Lásd: http://www.ronatabak.hu/images/Levél_a_kereskedelmi_partnereknek.pdf

${ }^{73}$ Egyik interjúalanyunk által használt fogalom.

${ }^{74}$ S.E.F.T. Kereskedelmi Kft., Práter Plusz Kereskedelmi és Szolgáltató Kft., Pannon Tobacco Kft. 


\section{A nettó vállalati árbevétel változása a dohányelosztó megalakulása után}

\begin{tabular}{|c|c|c|c|}
\hline Vállalat & $\begin{array}{l}\text { Értékesítés nettó } \\
\text { árbevétel }(\mathrm{Ft}) 2014\end{array}$ & $\begin{array}{l}\text { Értékesítés nettó } \\
\text { árbevétel (Ft) } 2016\end{array}$ & $2016 / 2014$ \\
\hline BAT Pécsi Dohánygyár & 100840783 & 116567038 & 115,6 \\
\hline Continental Dohányipari Zrt. & 25738919 & 24225312 & 94,1 \\
\hline $\begin{array}{l}\text { Imperial Tobacco } \\
\text { Magyarország } \\
\text { Dohányforgalmazó Kft. }\end{array}$ & 75059277 & 53201303 & 70,9 \\
\hline $\begin{array}{l}\text { Universal Leaf Tobacco } \\
\text { Magyarország Zrt. }\end{array}$ & 6221433 & 5124973 & 82,4 \\
\hline $\begin{array}{l}\text { RÓNATABAK } \\
\text { Dohányforgalmazó Kft. }\end{array}$ & 16316187 & 8259013 & 50,6 \\
\hline $\begin{array}{l}\text { Tabán Trafik Magyarország } \\
\text { Zrt. }\end{array}$ & 23857006 & 978527 & 4,1 \\
\hline JTI Hungary Zrt. & 57324931 & 49966262 & 87,2 \\
\hline $\begin{array}{l}\text { Philip Morris Magyarország } \\
\text { Kft. }\end{array}$ & 184991066 & 154784043 & 83,7 \\
\hline Alföld Tabak Kft. & 3847804 & 4488770 & 116,3 \\
\hline Danczek Dohányipari Kft. & 890176 & 1059205 & 119,0 \\
\hline
\end{tabular}

Forrás: http://e-beszamolo.im.gov.hu/

2014 és 2016 között jelentősen változott a talpon maradt vállalatok - éves forgalom és átlagos létszám alapján mért - teljesítménye. A változások egyértelmü nyertesei az Országos Dohánybolt Ellátó tulajdonosai: a BAT növelte, a Continental lényegében stabilizálta forgalmát ${ }^{75}$ és az alkalmazottak létszámát, miközben a kizárólag az ODBE közvetítésével kereskedőknél a forgalom és a létszám - néhány kisebb vállalat kivételével - jelentősen visszaesett (lásd a 4. és 5. táblázatot).

${ }^{75}$ A teljes és a belföldi forgalom között alig van eltérés, a hazai nagykereskedők nagy többsége nem exportál, csupán néhány cég szállít kisebb mennyiségeket külső piacokra is. 
A létszám változása a dohány-nagykereskedelmi vállalatoknál (fö)

\begin{tabular}{lccc}
\hline Vállalat & $\begin{array}{c}\text { Átlagos statiszti- } \\
\text { kai létszám 2014 }\end{array}$ & $\begin{array}{c}\text { Átlagos statiszti- } \\
\text { kai létszám 2016 }\end{array}$ & 2016/2014 \\
\hline BAT Pécsi Dohánygyár & 456 & 550 & 120,6 \\
Continental Dohányipari Zrt. & 323 & 316 & 97,8 \\
$\begin{array}{l}\text { Imperial Tobacco Magyarország } \\
\text { Dohányforgalmazó Kft. }\end{array}$ & 147 & 93 & 63,2 \\
Universal Leaf Tobacco Magyaror- & 25 & 24 & 96,0 \\
szág Zrt. & 128 & 110 & 85,9 \\
RÓNATABAK Dohányforgalmazó & 83 & 52 & 62,7 \\
Kft. & 132 & 87 & 65,9 \\
Tabán Trafik Magyarország Zrt. & 414 & 169 & 40,8 \\
JTI Hungary Zrt. & 47 & 12 & 25,5 \\
Philip Morris Magyarország Kft. & 7 & 7 & \\
Alföld Tabak Kft. & & & \\
Danczek Dohányipari Kft. & & & \\
\hline
\end{tabular}

Forrás: http://e-beszamolo.im.gov.hu

\section{Miért alakították át a dohánykereskedelem-ellátást?}

Következő kutatásunkban rekonstruáltuk és dokumentáltuk a dohánytermékek hazai piacán 2014 és 2017 között lezajlott folyamatokat. A 2014-es választások után a nemzeti dohányboltok és a dohányárusításra kijelölt kisboltok száma stabilizálódott. A trafikügyet kísérő közérdeklődés és izgatottság jelentősen csökkent. A 2012-ben felállított-létrejött új piacszerkezet gyengeségei és feszültségei (feketekereskedelem, nagy különbségek a dohányboltok jövedelmezőségében, a veszteséges vagy kis nyereséget hozó boltok tartósan nagy száma és hányada) azonban fennmaradtak, ezért újabb - nem különösebben sikeres - szabályozómódosításokra került sor a választások után. Tanulmányunkban bemutattuk, hogy a piac ilyen állapotában az állam radikálisan átalakította a hazai dohánytermék-nagykereskedelmet.

Az átszervezés „hivatalos” indoka a nagykereskedők erőfölénye volt. Azonban az eröfölény és következményei nem térnek el különösebben a hazai piacon megfi- 
gyelhető hasonló helyzetektől - önmagában ezért nem magyarázzák az ODBE létrehozását, még kevésbé a tulajdonosi szerkezetét, azt ugyanis, hogy a dohányboltellátó tulajdonosai egyúttal a hazai dohánytermékpiac jelentős beszállítói. Miért alakítottak ki egy magyar gazdaságban egyedülálló dohányboltellátó vállalatot?

Ez a különös tulajdonosi és versenyszerkezet erősíti azt a történetértelmezést, hogy a Continental csoport tulajdonosa a kormány és a Fidesz egyik vezetöjéhez füzödö, erös kapcsolatait felhasználva befolyásolta a piac szabályozását és hozott létre a vállalata számára elönyös helyzeteket. „Hamarosan elstartol a központi dohányellátó, és a trafikosztáskor taroló, Lázár Jánossal jó kapcsolatokat ápoló Continental csoport megint jó közel került a húsos fazékhoz. A kormány a jelek szerint eltökélt abban, hogy naggyá növeszti a társaságot. Eddig nem látszanak a siker jelei, de a versenytársak már kaptak egy nagy, tartósnak igérkezö különadót, és lecsúsztak a tízmilliárdos üzletnek igérkezö központi dohányellátóról." 76

Cikkünkben is dokumentáltuk a Continental csoport kivételezett helyzetét, ám ez önmagában nem magyarázta, hogy miért hozták létre pont ezen a piacon a magyar gazdaságban egyedülálló, ${ }^{77}$ a kis- és a nagykereskedők/termelők közé ékelt, elosztó vállalatot? Feltételezésünk szerint a dohánytermékpiac szabályozásának újabb kudarcai is hozzájárultak az ODBE megalapításához. Ez nemcsak a hasznok sajátos újraelosztását teszi lehetővé, de a dohánytermék-kiskereskedelmi piac állandó zavarainak megszüntetésével is kecsegtet. A történet folytatódik.

Az esetleírás elméleti hozadékkal is járt. Dokumentáltuk, hogy a piacfejlődés szakaszai késleltetve is követhetik egymást egy termék, egy termékcsoport, egy szolgáltatás piacának egyes szegmenseiben vagy szintjein. Neil Fligstein [2011] korábban bemutatott piacfejlődés-modellje kiterjeszthető az ilyen esetekre is.

${ }^{76}$ Lásd: http://hvg.hu/vallalat_vezeto/20150613_Kozponti_dohanyellato. A különadó említése az egészségügyi hozzájárulás történetére utal. Azzal az indoklással, hogy „a dohánygyártó vállalkozások maguk nem arányosan járulnak hozzá a közkiadásokhoz" az egészségügyi hozzájárulás mértékét a nettó árbevétellel mért vállalatnagyság szerint eltérően vetették ki. „Az új hozzájárulás 30 milliárd forintos árbevételig 0,2 százalék, a 30 milliárdot meghaladó, de a 60 milliárd forintot el nem érő bevétel után 2,5 százalék, a 60 milliárdot meghaladó bevétel után pedig 4,5 százalék lesz.” A sávos hozzájárulás-fizetés nagy vesztesei a külföldi tulajdonban levő nagyvállalatok, nyertese pedig a kisebb vállalatok körébe tartozó Continental csoport. A becslések szerint a Philip Morrisnak 6,2 milliárd forintnyi a befizetési kötelezettsége, a Continental legfeljebb 50 millió befizetésére kényszerül (Tamás, 2014).

${ }^{77}$ Hasonló szervezetek müködnek Olaszországban, Ausztriába, Svájcban - ezekkel itt most nem foglalkozunk. 


\section{Irodalomjegyzék}

Dr. Alexa Noémi - Dr. Burai Petra - Dr. Inzelt Éva [2012]: A lobbizás helyzete és szabályozása. Transparency International Magyarország, Budapest.

Antal László [1985]: Gazdaságirányítási és pénzügyi rendszerünk a reform útján, Közgazdasági és Jogi Könyvkiadó, Budapest.

Batka Zoltán [2014a]: Megállíthatatlan a feketekereskedelem. Karcsúsítanak a piacvezetők. Népszabadság, július 5., 9. o.

Batka Zoltán [2014b]: Dohányipar Egyetlen nagykereskedőre bízza a kormány a trafikok ellátását. Népszabadság, november 15., 6. o.

Batka Zoltán [2014c]: Trafikmutyi 2.0. Biztos üzletet kap a kormány szerint megbízható vállalkozás. Nagyot drágul a cigaretta. Népszabadság, december 16.

Batka Zoltán [2015a]: Sokadjára pályáztatják a falusi koncessziókat. Elmarad a trafikforradalom. Népszabadság, április 8., 6. o.

Batka Zoltán [2015b]: Kerekedik a bomba üzlet. Tovább módosulnak a trafikok ellátásáról szóló jogszabályok. Népszabadság, május 26., 5. o.

Fligstein, Neil [2001]: The Architecture of Markets. An Economic Sociology of Twenty-First-Century Capitalist Societies. Princeton University Press, Princeton-Oxford.

Gács János - Lackó Mária [1974]: Népgazdasági szintủ tervezési magatartás elemzése. Közgazdasági Szemle, XXI. évf., 2. sz., 257-274. o.

Gould, John P. [1973]: The Economics of Legal Conflicts. Journal of Legal Studies, 279.

Hirschman, Albert $O$. [1995]: Kivonulás, tiltakozás, hủség. Osiris Kiadó, Budapest.

Igan, D. - Mishra, P. - Tressel, T. [2009]: A Fistful of Dollars: Lobbying and the Financial Crisis. IMF Working Paper, No. 289.

Johansen, Leif [1981]: Az alkudozó társadalom és az alku eredménytelensége. Gazdaság, Vol. 15., No. 4., 101-118. o. Eredeti megjelenés: The bargaining society and the inefficiency of bargaining. Kyklos, Vol., 32, Issue 3., 497-522. o., augusztus (fordította: Farkas Katalin).

Kaiser, R. [2009]: So Damn Much Money: The Triumph of Lobbying and the Corrosion of American Government. Knof Publishers, New York.

Karsai Gábor [1988]: Ellátási felelősség vagy piacorientáció? Közgazdasági és Jogi Könyvkiadó, Budapest.

Kornai János [1957]: A gazdasági vezetés túlzott központosítása Közgazdasági és Jogi Könyvkiadó, Budapest.

Kornai János - Lipták Tamás [1965]: Two-Level Planning. Econometrica, Vol. 33., No. 1. (Jan), 141169. o.

Laki Mihály [2011]: A termék-és szolgáltatáspiacokátalakulása 1989 után. MTA Közgazdaságtudományi Intézet, Budapest.

Laki Mihály [2014]: A trafikpiac átalakulása és átalakítása: esettanulmány. MTA KRTK Közgazdaságtudományi Intézet, Mủhelytanulmányok - Discussion Papers, 10. sz.

Laki Mihály [2015a]: A trafikpiac átalakulása és átalakítása (esettanulmány). Szociológiai Szemle, 25. évf., 3. sz., 23-52. o.

Laki Mihály [2015b]: Restructuring and re-regulation of the Hungarian tobacco market. Corvinus Journal of Sociology and Social Policy, 6. évf, 2. sz.

Lowry S., Todd [1976]: Bargain and Contract Theory in Law and Economics. Journal of Economic Issues, Vol. X., No. 1., 1-22. o.

Merton, Robert [1936]: The Unanticipated Consequences of Purposive Social Action. American Economic Review, Vol. 1., Issue 6., 894-904. o. 
Muthoo, Abhinay [1999]: Bargaining theory with applications. Cambridge University Press.

Muthoo, Abhinay [2000]: A Non-Technical Introduction to Bargaining Theory. World Economics, Vol. 1., No. 2.

Tamás Gábor [2014]: Ezt is letüdözik. Központosítják a dohány-nagykereskedelmet is. Magyar Narancs, november 27., 15. o.

Vidal, Jordi, Blanes - Draca, Mirko - Fons-Rosen, Christian [2011]: The power of K Street: New research on the economics of lobbying. CESifo DICE Report, No. 1. 